\title{
Measurement and Analysis of Mass Flow and Abrasive Sieving Impact on Technological Head Vibrations during Cutting Abrasion Resistant Steels with Abrasive Water Jet Technology
}

\section{Stanislav Fabian, Štefánia Salokyová}

Faculty of Manufacturing Technologies, Department of Manufacturing Processes Operation, Technical University of Košice, Bayerova 1, 08001 Prešov, Slovakia. E-mail: stanislav.fabian@tuke.sk, stefania.salokyova@tuke.sk

The article presents the results of Technical University in Košice Faculty of Manufacturing Technologies Department of production processes operation and Technical University in Ostrava Physics Institute Liquid jet workplace cooperation in the area of operational states diagnosis of manufacturing systems with abrasive water jet technology (AWJ). Within the operational states diagnostics is the impact of selected technological parameters on technological head vibrations studied. Based on an extensive set of experiments are original graphical dependences determined of the abrasive mass flow and abrasive sieving impact on the vibrations parameter - technological head vibrations acceleration amplitude of manufacturing system with AWJ technology. In addition to the original graphical dependences are in article new knowledge formulated in the area of science and research and recommendations for companies that operates manufacturing systems with AWJ technology.

Keywords: Casting HARDOX 500, Cutting, Hydro-abrasive water jet, Abrasive mass flow rate, vibrations acceleration amplitude

\section{Acknowledgement}

The research work was supported by the Project of the SF of the EU, Operational Programme Research and Development, Measure 2.2 Transfer of knowledge and technology from research and development into practice, project: Research and development of intelligent nonconventional actuators based on artificial muscles. ITMS code: 26220220103, projects VEGA 1/0409/13 and KEGA 027 TUKE - 4/2014.

\section{References}

[1] SERVÁTKA, M. (2009). Modelling, simulation and optimization of technological parameters related to requested product quality in manufacturing technologies with water jet. Dissertation. Prešov, 125 p.

[2] PLANČÁR, Š. (2012). Modelling and simulation of influence of selected material and technological parameters in AWJ machining of steel. FVT Prešov

[3] FABIAN, S., SALOKYOVÁ, Š. (2012). Experimental verification of abrasive mass flow impact on the technological head acceleration amplitude and vibrations frequency in the production system with AWJ technology. In: Manufacturing technology. 12 12, 18-21.

[4] FABIAN, S., SALOKYOVÁ, Š., JACKO, P. (2012). Experimental verification of the freqeuncy spectrum of unwear and wears guidance tube on the technological head vibrations creation in the production system with AWJ technology. In: Manufacturing Technology. 12 13, $105-108$.

[5] FABIAN, S., SALOKYOVÁ, Š., OLEJÁR, T. (2011). Analysis and experimental study of the technological head feed rate impact on vibrations and their frequency spectra during material cutting using AWJ technology. In: Nonconventional Technologies Review. 4, 27-32.

[6] KMEC, J., BIČEJOVÁ, L., KRENICKÝ, T. (2011). AWJ production technology system technology head vibrations formation due to water press changes. In: Annals of Faculty of Engineering Hunedoara. 9. 3, 343-344.

[7] BIČEJOVÁ, L. (2013). Water jet technology head vibration generation due to selected technology parameters fluctuation effect during alloy cutting. In: Applied Mechanics and Materials. 308, 81-86.

[8] KALIČINSKÝ, J. (2009). Control of technological parameters of liquid jet in violation of materials. Dissertation. Ostrava,

[9] HREHA, P. (2012). Study of processes resulting from the hydroabrasive disintegration of metallic materials by vibration, Dissertation. Prešov, 303 p.

[10] BIČEJOVÁ, L. (2010). Modelling and simulation of operational conditions influencing the formation and extent of vibrations in manufacturing systems, Dissertation. Prešov, $184 \mathrm{p}$.

[11] JACKO, P. (2011). Modelling and simulation of technological parameters related to usage of non-traditional abrasives in AWJ technology, Dissertation. Prešov, 163 p. 
[12] SALOKYOVÁ, Š. (2012). Analysis, modelling and simulation of vibrations in manufacturing systems with water jet technology, Dissertation. Prešov, 303 p.

[13] HASHISH, M. (1991). In: Journal of Engineering for Industry, 1, 29-37

[14] MAŇKOVÁ, I. (1995). Progressive Technologies. Košice: TU Košice, Faculty of Mech. Engineering, 2000,275 p.

[15] SUMMERS, A. D. Water jetting Technology, Oxford, 882

[16] STRAKA, L' (2004). Optimization of automated quality control of manufacturing processes in engineering applications in the electrical discharge machining technology, Dissertation. Prešov, 135 p.

[17] KREHEL', R. (2011). In: Scientific Papers : operation and diagnostics of machines and production systems operational states. Lüdenscheid, RAM-Verlag, pp. 23-27

[18] KRENICKÝ, T. (2011). Scientific Papers: In: Operation and Diagnostics of Machines and Production Systems Operational States. 4. 5-8pp.

[19] JURKO, J., PANDA, A., BEHÚN, M. (2012). In: Applied Mechanics and Materials, Trans Tech Publications, Zurich, Switzerland, 224 142, 142-145

Copyright (C) 2015. Published by Manufacturing Technology. All rights reserved. 